\title{
MAJELIS RAKYAT PAPUA \\ DAN \\ PEMBERDAYAAN ORANG ASLI PAPUA
}

Oleh : Usman Pakasi

Abstract

Usman Pakasi : Papua People Council and Empowering Indigenous People. (Promotor: T.R. Andi Lolo, Pawennari Hijjang, and Edward Poelinggomang).

The objective of this research is to find out theoretical understanding about role of Papua Council in empowering local people. The study conducted thoroughly by using qualitative method and phenomenologic strategy.

The location of this research is based on the object its material where the institution located, namely in Jayapura city. The empiric obtained through interview technique, observation, and other secondary data.

The result of research shows that Papua People Council is the cultural representation of the indigenous peple of Papua that consist of traditional people, women and religion. This institution plays role in keeping the interest and protecting Papua people's rights by doing supervision upon government policy.

The empowerment of local people specially related to tradisional people, women and religion. The empowerment related to the economy, social, culture, politic, and law. The empowerment intended to give the advantage for the prosperity and the sense of justice for the indigenous people of Papua in development.

\section{Abstrak}

Usman Pakasi: Majelis Rakyat Papua dan Pemberdayaan Orang Asli Papua (Promotor : T.R Andi Lolo, Pawennari Hijjang, dan Edward Poelinggomang.

Penelitian ini bertujuan mencari pemahaman teoritis tentang peranan Majelis Rakyat Papua dalam pemberdayaan masyarakat lokal. Studi dilakukan secara mendalam dengan menggunakan metode kualitatif dengan strategi fenomenologik.

Lokasi Penelitian ini disesuaikan dengan objek materialnya di mana lembaga ini berkedudukan yaitu kota Jayapura. Data empiris diperoleh 
melalui teknik wawancara mendalam, pengamatan, dan data sekunder lainnya.

Hasil Penelitian menunjukkan bahwa MRP merupakan representasi kultural orang asli Papua yang terdiri dari masyarakat adat, perempuan, dan agama. Lembaga ini berperan dalam menjaga kepentingan dan perlindungan hak-hak dasar orang Papua dengan melakukan pengawasan terhadap kebijakan pemerintah.

Pemberdayaan masyarakat lokal terutama yang berhubungan dengan pemberdayaan masyarakat adat, perempuan dan agama. Pemberdayaan menyangkut ekonomi, sosial, budaya, politik dan hukum. Pemberdayaan dimaksudkan untuk memberikan manfaat yang sebesar-besarnya bagi kejahteraan dan rasa keadilan bagi orang asli Papua dalam pembangunan.

\section{LATAR BELAKANG}

Keputusan politik menggabungkan Provinsi Irian Barat (Papua) menjadi bagian dari Negara Kesatuan Republik Indonesia sejak tahun I963 ternyata masih belum menghasilkan kesejahteraan, kemakmuran dan pengakuan terhadap hak-hak dasar rakyat Papua. Kesejahteraan masyarakat terutama dalam bidang ekonomi, politik, kesehatan, pendidikan dan kebudayaan, masih sangat memprihatinkan. Beberapa kebijakan pemecahan masalah dilakukan oleh pemerintah pusat, di antaranya dengan melakukan pemekaran propinsi dengan maksud untuk mempercepat pembangunan. Tetapi kebijakan ini justru mendapat reaksi keras dari masyarakat di daerah ini. Kesenjangan sosial, ekonomi, dan politik di Papua dengan daerah-daerah lainnya di Indonesia adalah ancaman terhadap integrasi Nasional.

Penyelesaian konflik Papua ditanggapi dengan pendapat yang berbeda dari masyarakat lokal. Ada kelompok yang tetap ingin berpisah dari negara kesatuan Republik Indonesia (merdeka), sementara kelompok lainnya menginginkan perbaikan kesejahteraan dan rasa keadilan dengan cara mempercepat pembangunan sosial ekonomi serta penyelesaiaan masalah pelanggaran HAM.

Kesepakatan otonomi khusus yang diambil adalah solusi terbaik untuk menyelesaikan konflik di Papua. Hasil kesepakatan ini direalisalikan di dalam Ketetapan Majelis Permusyawaratan Rakyat Republik Indonesia Nomor IV/MPR/1999, tentang Garis-Garis Besar Haluan Negara (GBHN) Tahun 1999-2004, yang menyangkut penetapan Provinsi Papua sebagai daerah otonomi khusus. Dalam Ketetapan MPR Nomor IV/MPR/2000, 
menekankan kembali tentang rekomendasi kebijakan dalam penyelenggaraan otonomi daerah yang ditujukan kepada Pemerintah dan Dewan Perwakilan Rakyat (DPR).

Pemberian otonomi khusus bagi Provinsi Papua dimaksudkan untuk mewujudkan keadilan, penegakan supremasi hukum, penghormatan terhadap HAM, percepatan pembangunan ekonomi, peningkatan kesejahteraan, dan kemajuan masyarakat Papua, dalam rangka kesetaraan dan keseimbangan dengan kemajuan provinsi lain.

Peran penting orang asli Papua dalam Undang-Undang Otonomi Khusus tercermin dengan pembentukan Majelis Rakyat Papua. Pembentukan lembaga ini dimaksudkan untuk mewadahi kepentingan rakyat asli Papua secara langsung, sehingga orang-orang yang duduk di dalamnya adalah orang asli Papua yang dipilih dari wakil adat, perempuan, dan agama.

Majelis Rakyat Papua merupakan representasi kultural orang asli Papua yang memiliki wewenang tertentu dalam rangka perlindungan hakhak dasar dengan berlandaskan pada penghormatan terhadap adat dan budaya, pemberdayaan perempuan, dan pemantapan kerukunan hidup beragama (PP Nomor 54 Tahun 2004).

Peranan Majelis Rakyat Papua sesuai dengan amanat Undang-Undang Otonomi Khusus adalah menjaga kepentingan dan hak-hak dasar orang asli Papua dalam bentuk pemberdayaan masyarakat lokal. Untuk memahami peran dan fungsi Majelis Rakyat Papua melalui suatu kajian dan pemahaman mendalam.

\section{Permasalahan}

Sehubungan dengan latar belakang tersebut, permasalahan penelitian ini berangkat dari suatu statement bahwa "Keberadaan Majelis Rakyat Papua dalam sistem pemerintahan di Provinsi Papua disebabkan oleh adanya kesenjangan dan rasa ketidakadilan yang dialami oleh rakyat Papua dalam pembangunan". Sehubungan dengan rumusan permasalahan dalam bentuk statement di atas, penelitian ini difokuskan pada bebarapa unsur sebagai berikut :

1. Latar belakang historis lahirnya Majelis Rakyat Papua dalam sistem pemerintahan di Provinsi Papua .

2. Peranan Majelis Rakyat Papua dalam memberdayakan masyarakat lokal (orang asli Papua) untuk mengatasi kesenjangan sosial ekonomi, budaya dan permasalahan politik di Papua. 
3. Peranan Majelis Rakyat Papua dalam dalam melindungi hak-hak dasar dan menciptakan rasa keadilan bagi orang asli Papua di tanah Papua.

\section{Tujuan Penelitian.}

Tujuan penelitian ini adalah mencari pemahaman teoritis tentang pemberdayaan masyarakat lokal melalui lembaga Majelis Rakyat Papua. Untuk mencapai tujuan penelitian ini, dilakukan studi dan kajian mendalam terhadap peran dan fungsi Majelis Rakyat Papua sebagaimana yang telah diamanatkan di dalam Undang-Undang Otonomi Khusus Papua.

Pentingnya untuk melakukan penelitian dan kajian terhadap permasalahan ini didasarkan pada beberapa pertimbangan, yaitu : (1) fenomena tersebut masih relatif baru dalam sistem pemerintahan, sehingga perlu mencari dan memahami bentuk dan model pelaksanaannya, (2) melakukan suatu studi mendalam yang dapat mengungkapkan permasalahan-permasalahan yang timbul berkaitan dengan pelaksanaan fungsi dan tugas Majelis Rakyat Papua.

\section{Kegunaan Penelitian.}

Kegunaan yang diharapkan dalam penelitiaan ini, dapat ditinjau dari segi ilmiah dan segi pragmatisnya. Secara ilmiah, hasil penelitian ini diharapkan dapat memperkaya pemahaman konsep tentang Majelis Rakyat Papua dari perspektif perubahan sosial.

Secara pragmatis, hasil penelitian ini diharapkan dapat memberikan sumbangan pemikiran terutama terhadap lembaga Majelis Rakyat Papua dan pihak-pihak terkait dalam hubungannya dengan pemberdayaan masyarakat lokal dan menghasilkan suatu teori substantif yang memberikan pemahaman terhadap pemberdayaan masyarakat.

\section{Metode penelitian}

Sehubungan dengan objek material dari permasalahan yang dibahas yaitu Majelis Rakyat Papua yang bertempat di Kota Jayapura, maka lokasi penelitian yang menjadi wilayah observasi dan pengumpulan data difokuskan daerah tersebut. Kota Jayapura merupakan ibu kota provinsi dan pusat kegiatan pemerintahan Provinsi Papua.

Metode yang digunakan dalam penelitian ini adalah metode kualitatif. Metode ini dimaksudkan untuk mengumpulkan dan menganalisis data serta memberikan interpretasi untuk menjawab permasalahan dan tujuan 
penelitian yang telah dirumuskan. Pendekatan kualitatif ini memaparkan data secara rasional dan empiris sesuai dengan desain penelitian.

Untuk mengumpulkan data dalam penelitian ini, digunakan informan yang meliputi sejumlah kerakteristik yang berpengaruh terhadap permasalahan yang diteliti atau yang berhubungan dengan peranan Majelis Rakyat Papua dalam pemberdayaan masyarakat lokal. Informan dicari dalam kumpulan populasi melalui pengamatan langsung di daerah penelitian.

Teknik pengumpulan data yang digunakan dalam penelitian ini sesuai dengan sifat penelitiannya yaitu deskriptif kualitatif. Pengumpulan pengamatan (observasi) dan wawancara. Data kualitatif yang dikumpulkan terutama berupa ucapan yang berwujut kata-kata, tulisan, perilaku yang diamati dari subjek (orang yang diamati) yang dinyatakan dalam bentuk simbolik seperti tafsiran dan interpretasi. Proses analisa data dilakukan secara induktif yang berlangsung bersamaan dengan proses penelitian. Data yang dihasilkan dianalisa secara kualitatif dan selanjutnya dideskripsikan secara sistematis. Analisa deskriptif dimaksudkan untuk menyederhanakan dan sekaligus menjelaskan keseluruhan data yang telah dikategorisasi dan diklasifikasi.

\section{Pendekatan Teoritis}

Lahirnya Undang-Undang Nomor 21 tahun 2001 tentang Otonomi Khusus bagi Provinsi Papua dan pembentukan Majelis Rakyat Papua adalah hal yang sangat mendasar terciptanya perubahan di Papua. Perubahan dimaksud adalah perubahan paradigm dalam melaksanakan pembangunan di Papua dengan memperioritaskan pemberdayaan terhadap orang asli Papua.

Majelis Rakyat Papua merupakan representasi kultural orang asli Papua yang berperan untuk melindungi hak-hak dasar dengan berlandaskan pada penghormatan terhadap adat dan budaya, pemberdayaan perempuan, dan pemantapan kerukunan hidup beragama (PP Nomor 54 Tahun 2004). Peran menurut Soekanto adalah menentukan bagaimana orang berperilaku, menuntut kewajiban-kewajiban tertentu, memberikan hak-hak tertentu, dan menentukan hubungannya dengan struktur sosial tertentu (Soekanto, $2007: 212$ ).

Sebagai lembaga kemasyarakatan MRP mempunyai kegunaaan sebagai alat pengamatan kemasyarakatan. Lembaga kemasyarakatan menurut Selo Soemarjan merupakan bagian-bagian pokok dari kebudayaan suatu 
masyarakatan yang berfungsi sebagai alat kontrol dan mengatur peri kelakuan sesuai dengan kehendak masyarakat (Selo Soemarjan dan Soeleman Soemardi : $1964: 63$ ).

Dalam hubungannya dengan konsep pemberdayaan, Liliey (1988) mengartikan pemberdayaan yaitu memberikan peran pada masyarakat lapisan bawa dalam keikutsertaan pada berbagai kegiatan pembangunan. Rappaport mengatakan bahwa pemberdayaan adalah suatu cara dengan mana rakyat, organisasi, dan komunitas diarahkan agar mampu menguasai kehidupannya (Suharto, 2005 : 59).

Pranarka dan Moeljarto mengemukakan bahwa kecenderungan primer pemberdayaan menunjuk pada proses memberikan atau mengalihkan sebagian kekuasaan, kekuatan, atau kemampuan kepada masyarakat agar setiap individu menjadi lebih berdaya (Wrihatnolo dan Dwidjowijoto, 2007 : 119). Narayan mengemukakan empat elemen kunci dalam pemberdayaan yaitu: akses informasi, partisipasi, akuntabilitas, dan kemampuan organisasi lokal (Narayan, 2002: 14 - 18).

Pemberdayaan masyarakat merupakan upanya untuk mengatasi masalah kesenjangan dalam pembangunan melalui suatu pemecahan masalah dengan cara memanfaatkan potensi yang ada dalam masyarakat. Menurut Kartasasmita, perencanaan pembangunan yang berorientasi pada pemberdayaan masyarakat harus meliputi: pertama, mengenali masalah mendasar yang menyebabkan terjadinya kesenjangan; kedua, mengidentifikasi alternatif untuk memecahkan masalah; dan ketiga, menetapkan alternatif yang dipilih dengan memperhatikan sumber daya yang tersedia dan dapat dimanfaatkan serta potensi yang dapat dikembangkan (Kartasasmita, 1996: 16).

Pendekatan teori sosiologi dalam studi ini terutama dari teori struktur fungsional dan teori konflik. Kedua teori membantu memahami bagaimana perubahan-perubahan terjadi dalam masyarakat. Sajogyo mengemukakan bahwa perubahan sosial adalah perubahan dalam hubungan interaksi antar orang, organisasi atau komunitas. Ia dapat menyangkut struktur sosial atau pola nilai dan norma serta peranan (Sajogyo, 1985 : 119),

Parsons sebagai salah satu tokoh sentral dalam teori struktur fungsional mengetengahkan dua sebab utama perubahan dalam sistem sosial, yaitu kecenderungan tak seimbang yang ada dalam setiap hubungan yang terjadi antara suatu sistem sosial dengan lingkungannya dan ketegangan yang hidup di antara unsur normatif dan struktural dari setiap sistem sosial (Eisenstadt, 1986 : 31). Parsons (Giddens, 2004 : 321) mengklasifikasi perubahan sosial berdasarkan atas prinsip di mana 
kecenderungan alamiah keseluruhan sistem adalah berupa upaya mempertahankan keseimbangan: jika ada keseimbangan karena tekanan atau konflik, sistem ini membenahi fungsi-fungsi yang cenderung mengguncang stabilitas. Ini merupakan akar kesulitan logika, yaitu adanya keinginan untuk mengartikulasikan analisis struktural dan dinamis dalam satu keseimbangan.

Perspektif teori konflik pada umumnya melihat masyarakat selalu dalam proses perubahan. Setiap element dalam masyarakat memberikan sumbangan terhadap disintegrasi dan perubahan. Keteraturan yang terjadi hanyalah karena adanya tekanan atau pemaksaan kekuasaan oleh golongan yang berkuasa (Ritzer, 1985 : 30 - 34).

Ralf Dahrendorf berpendapat bahwa konflik sosial mempunyai sumber struktural, yakni hubungan kekuasaan yang berlaku dalam struktur organisasi sosial. Konflik antar kelompok dapat dilihat dari sudut konflik tentang keabsahan hubungan kekuasaan yang ada (Lauer, 2003 : 281).

Dahrendorf menjelaskan bahwa konflik memimpin ke arah perubahan dan pembangunan. Dalam situasi konflik, golongan yang terlibat melakukan tindakan-tindakan untuk mengadakan perubahan dalam struktur sosial. Segera setelah konflik muncul, kelompok itu melakukan tindakan yang menyebabkan perubahan dalam struktur sosial (Ritzer dan Goodman, 2004 : 157 dan Ritzer, 1985 : 33).

Lewis Coser melihat konflik sebagai katup penyelamat, yaitu salah satu mekanisme khusus yang dapat dipakai untuk mempertahankan kelompok dari kemungkinan konflik sosial, membantu membersihkan suasana dalam kelompok yang sedang kacau, sebagai jalan keluar untuk meredahkan permusuhan dan memungkinkan pengungkapan rasa tidak puas terhadap struktur (Poloma, 1992, 109 - 120).

\section{Hasil Penelitian}

Keinginan politik pemerintah Republik Indonesia untuk menyelesaikan permasalahan di Provinsi Papua secara sungguh-sungguh baru dimulai pada tahun 1999, yang ditandai dengan penetapan daerah ini sebagai daerah otonomi khusus. Pemberian otonomi khusus tersebut dimaksudkan untuk mewujudkan keadilan, menegakkan supremasi hukum, penghormatan dan penegakan HAM, peningkatan kesejahteraan dan kemajuan rakyat Papua dalam rangka kesetaraan dan keseimbangan dengan provinsi lain.

Hal yang menonjol dalam otonomi khusus adalah diakomodasikannya lembaga Majelis Rakyat Papua. Pembentukan lembaga ini dilatarbelakangi oleh beberapa hal yakni: 1) hak-hak politik orang asli Papua dan kaum perempuan cenderung diabaikan; 2) representasi politik orang asli Papua 
dan kaum perempuan di lembaga leglslatif daerah dan partai politik tidak signifikan; 3) aspirasi orang asli Papua dan kaum perempuan di lembaga cenderung tidak diakomodasi; 4) partisipasi politik orang asli Papua dan kaum perempuan relatif rendah; 5) komitmen untuk menghormati adat dan budaya, memperdayakan kaum perempuan, dan memantapkan kerukunan hidup beragama; dan 6) komitmen untuk melakukan rekonsiliasi antara sesama orang asli papua, maupun orang asli Papua dengan sesama penduduk Provinsi Papua.

Majelis Rakyat Papua adalah lembaga representasi kultural orang asli Papua yang dibentuk sebagai wadah rekonsiliasi untuk menjembatani perbedaan politik antara pemerintah dan rakyat Papua terhadap status politik Papua. Perbedaan ini terutama terhadap pelaksanaan Pepera yang dianggap tidak sah oleh orang Papua karena pelaksanaannya tak sejalan dengan Perjanjian New York, yaitu satu orang satu suara.

Landasan hukum pembentukan MRP adalah UU Nomor 21 Tahun 2001 dan Peraturan Pemerintah Nomor 54 Tahun 2004. Sebagaimana dijelaskan dalam peraturan tersebut bahwa pembentukan lembaga ini merupakan representasi kultural orang asli Papua yang terdiri dari adat, perempuan dan agama. Peraturan tersebut menempatkan orang asli Papua sebagai subyek utama dalam penyelenggaraan pemerintahan dan pembangunan dan menekankan perlunya pengakuan dan penghormatan terhadap hakhak dasar orang asli Papua.

Tugas dan wewenang MRP sebagaimana telah dijelaskan dalam Undang-Undang Otonomi Khusus adalah : 1) memberikan pertimbangan dan persetujuan terhadap bakal calon Gubernur dan Wakil Gubernur yang diusulkan oleh DPRP. 2) memberi pertimbangan dan persetujuan terhadap anggota MPR RI utusan daerah Provinsi Papua yang diusulkan oleh DPR; 3) memberikan pertimbangan dan persetujuan terhadap rancangan perdasus yang diajukan oleh DPRP bersama-sama dengan gubernur; 4) memberi saran, pertimbangan, dan persetujuan terhadap rencana perjanjian kerjasama yang dibuat oleh pemerintah maupun pemerintah provinsi dengan pihak ketiga yang berlaku di Provinsi Papua khususnya yang menyangkut perlindungan hak-hak orang asli Papua. 5) memperhatikan dan menyalurkan aspirasi, pengaduan masyarakat adat, umat beragama, dan kaum perempuan dan masyarakat pada umumnya yang menyangkut hak-hak orang asli Papua, serta memfasilitasi tindak lanjut penyelesaiannya. 6) memberi pertimbangan kepada DPRP, Gubernur, DPR kabupaten/kota dan bupati/walikota mengenai hal-hal yang terkait dengan perlindungan hak-hak orang asli Papua. 
Pembentukan MRP dimaksudkan untuk ikut berperan dalam menentukan dan mengawasi kebijakan-kebijakan pemerintah terutama yang berhubungan dengan penduduk asli. Peran dan fungsi lembaga ini terutama untuk mengawal dan mengawasi otonomi khusus agar pelaksanaannya difokuskan untuk meningkatkan kesejahteraan dan melindungi hak-hak dasar orang asli Papua. Sebagai lembaga representasi kultural, lembaga ini menjalankan peran dan fungsi sesuai dengan amanat otonomi khusus. Dalam Menjalankan tugas dan fungsi, lembaga ini berlandaskan pada penghormatan terhadap adat dan budaya, pemberdayaan perempuan, dan pemantapan kerukunan hidup beragama.

Lahirnya MRP dalam sistem pemerintahan di Papua merupakan upaya memberdayakan orang asli Papua. Hal ini merupakan salah satu penegasan -dalam Undang-Undang Nomor 21 Tahun 2001. Kebijakan ini diambil oleh pemerintah sebagai solusi untuk menyelesaikan berbagai permasalahan di Papua terutama masalah kesenjangan sosial, ekonomi, politik dan hukum. Permasalahan ini terjadi sehubungan dengan ketimpangan dan kekeliruan yang terjadi dalam pembangunan di masa lalu, yang menempatkan orang asli Papua berada pada posisi pinggiran.

Pemberdayaan masyarakat lokal terutama yang berhubungan dengan masyarakat adat, perempuan dan agama. Pemberdayaan masyarat adat adalah hal yang penting untuk memperkuat kelembagaan adat di Papua, dengan memberikan peran dalam mengelola sumber daya alam sesuai dengan nilai-nilai/hukum adat yang di anut. Dengan pemberdayaan ini secara serius menempatkan posisi masyarakat adat dan hak-hak masyarakat adat pada posisi yang layak

Pemberdayakan masyarakat adat terutama yang berhubungan dengan persoalan tanah adat dan hak ulayat. Ini merupakan salah satu peran dan tugas MRP untuk menyelesaikan persoalan tanah adat yang selama ini merugikan masyarakat adat. Tanah mempunyai arti dan fungsi yang strategis bagi masyarakat adat, sehingga hak mereka perlu mendapat jaminan hukum.

Pemberdayaan terhadap perempuan di Papua mendapat penanganan serius setelah diberlakukannya UU Otonomi Khusus. Undang-undang ini menegaskan tentang kewajiban pemerintah daerah baik di tingkat provinsi maupun kabupaten untuk menegakkan hak azasi kaum perempuan terutama menyangkut pembinaan, perlindungan, dan pemberdayaan serta memposisikan kaum perempuan sebagai mitra sejajar dengan kaum lakilaki. 
Keterlibatan perempuan di dalam salah satu kelompok kerja MRP membawa paradigma baru dalam penyelesaian permasalahan perempuan di Papua, karena kaum perempuan khususnya orang asli Papua telah menjadi bagian penting untuk ikut mengambil bagian dalam proses pembangunan. Perhatian terhadap perempuan asli Papua ini juga dilatarbelakangi oleh kondisi mereka yang selama ini ditempatkan pada posisi yang tidak menguntungkan dalam berbagai aspek kehidupan. Mereka senantiasa menjadi korban kekerasan baik yang terjadi dalam rumah tangga, kekerasan kultural maupun kekerasan pemerkosaan yang dilakukan oleh oknum-oknum tertentu. Kebijakan-kebijakan dalam politik juga ikut mewarnai permasalahan perempuan di Papua, di mana keterlibatan mereka sangat minim, baik pada jabatan-jabatan di pemerintahan maupun keterwakilan mereka di wakil rakyat. Dalam bidang pendidikan pun mereka kurang mendapat perhatian dibandingkan dengan laki-laki.

Masuknya kelompok agama menjadi bagian kelompok kerja MRP dimaksudkan untuk membicarakan situasi damai atau kerukunan umat beragama di Papua. Kelompok kerja agama membicarakan tentang bagaimana kegiatan-kegiatan yang dilakukan, baik di bidang pendidikan, maupun pembinaan umat beragama yang berada di bawah lembaga keagamaan. Untuk menjamin hak dan kebebasan menjalankan ibadah sesuai dengan ajaran masing-masing yang dianut oleh penduduk Papua, lebih lanjut diatur dalam peraturan daerah khusus (perdasus).

Agama hendaknya tidak hanya menjalankan fungsi kontrol saja, melainkan juga sebagai pelaksana dari pemberdayaan itu sendiri. Inilah yang dimaksud dengan perluasan wilayah jangkauan gerakan keagamaan. Hal ini bisa dilakukan dengan cara komunikasi antar umat beragama dan mencari rumusan yang tepat untuk memberdayakan para pemeluknya yang dilanda kemiskinan. Agama harus dipahami sebagai salah satu struktur institusional penting yang melengkapi keseluruhan sistem sosial. Agama tidak hanya dipandang sebagai ibadah rutin belaka, tetapi lebih dari itu melingkupi seluruh segmen kehidupan manusia.

Otonomi khusus dan pembentukan MRP di Provinsi Papua telah membawa pendekatan baru dalam pelaksanaan pembangunan ekonomi. Pembangunan ekonomi terutama ditujukan kepada penduduk asli Papua yang selama ini terabaikan. Karena itu, rakyat Papua melalui lembaga MRP dlibatkan secara nyata untuk mengawal dan mengawasi semua jenis kegiatan ekonomi. Pembangunan ekonomi di Provinsi Papua, termasuk pemamfaatan sumber daya alam, dilakukan dengan memberikan mamfaat 
yang sebesar-besarnya bagi kemakmuran dan kesejahteraan bagi rakyat Papua, dengan tetap menjunjung tinggi rasa keadilan, pemerataan, perlindungan terhadap masyarakat adat, perempuan dan bidang keagamaan. Pemberdayaan dalam bidang ekonomi adalah hal yang sangat mendasar untuk meningkatkan kesejahteraan masyarakat terutama orang asli Papua.

Pemberdayaan ekonomi kerakyatan perlu memperoleh prioritas dalam pembangunan ekonomi di Provinsi Papua. Ekonomi kerakyatan dapat menjadi pelaku utama dalam perekonomian, terutama dengan pengalaman masa krisis yang melanda perekonomian nasional dewasa ini. Berdasarkan perspektif tersebut, titik berat berat pemberdayaan ekonomi kerakyatan akan terletak pada upaya mempercepat pembangunan pedesaan/kampung sebagai tempat bermukim dan berusaha sebagian besar subyek dan obyek pembangunan orang asli Papua), di mana mereka berusaha sebagai petani dan nelayan yang berpolakan subsistence level.

Dari aspek budaya, Provinsi Papua memiliki keragaman suku, bahasa dan adat istiadat. Dengan keanekaragaman yang sekaligus merupakan potensi kekayaan yang besar dalam rangka membangun kebudayaan nasional. Oleh karena itu, Nilai budaya dan aspek-aspek kultural harus dijaga, dilestarikan, dan difungsikan secara faktual dalam kehidupan masyarakat.

Dalam hubungannya dengan pengembangan kualitas sumber daya manusia, terutama berhubungan dengan pendidikan dan kesehatan. Hal ini menjadi salah satu perioritas MRP dalam menjalankan tugasnya untuk memberdayakan orang asli Papua dalam sektor pendidikan dan kesehatan. MRP mengharapkan agar kedua sektor ini mendapat perhatian serius terutama di daerah pedesaan. Kedua bidang ini lebih lanjut diatur dalam perdasus dan perdasi sebagai landasan berpijak sesuai dengan amanat otonomi khusus.

\section{Kesimpulan}

Berdasarkan paparan dan analisis yang telah diuraikan di atas, dapat ditarik beberapa kesimpulan sebagai berikut:

1. Latar belakang historis keberadaan Majelis Rakyat Papua dalam sistem pemerintahan adalah merupakan upaya untuk menyelesaikan permasalahan kesenjangan sosial ekonomi, budaya dan politik, serta rasa keadilan khususnya terhadap orang asli Papua. 
2. Majelis Rakyat Papua merupakan representasi kultural orang asli Papua yang terdiri dari wakil adat, wakil perempuan, dan wakil agama. Ketiga aspek tersebut, merupakan satu kesatuan kultural seluruh orang Papua. Difokuskannya lembaga ini pada ketiga aspek kultural tersebut karena ternyata ketertinggalan yang sangat jauh adalah ketiga bidang ini dan belum mendapat perhatian dalam pembangunan

3. Peranan Majelis Rakyat Papua adalah menjaga kepentingan dan perlindungan hak-hak dasar orang asli Papau, terutama untuk mengawal dan mengawasi pelaksanaan otonomi khusus dan memberikan pertimbangan terhadap pemerintah dalam menjalankan kebijakan pembangunan.

4. Pemberdayaan masyarakat lokal mencakup pemberdayaan masyarakat adat, masyarakat perempuan dan agama.

5. Pemberdayaan ekonomi, sosial, budaya dan politik merupakan upaya untuk meningkatakan kesejahteraan dan rasa keadilan khususnya terhadap orang asli Papua dalam pembangunan. Pemberdayaan dilakukan dengan memberikan manfaat sebesar-besarnya bagi kesejahteraan rakyat Papua dengan tetap menjunjung tinggi rasa keadilan, pemerataan, perlindungan masyarakat adat, perempuan, dan agama serta pelestarian lingkungan dan pembangunan yang berkelanjutan

\section{Daftar Pustaka}

Eisenstadt. 1986. Revolusi dan Transformasi Masyarakat. Rajawali, Jakarta. Giddens, Anthony dkk. 2004. Sosiologi, Sejarah dan Berbagai Pemikirannya, di Indonesiakan oleh Ninik Rochani Syam, Kreasi Wacana, Yogyakarta.

Lauer, Robert H. 2003. Perspektif tentang Perubahan Sosial, (cet-4) terjemahan Alimandan, PT Rineka Cipta, Jakarta.

Liliey, Gayatri, 1998. Pemberdayaan Masyarakat Pesisir di Sekitar Kawasan Konservasi Laut, Jurnal Pembangunan Daerah No. 2 Depdagri, Jakarta.

Peraturan Daerah Provinsi Nomor 5 Tahun 2005. Pembentukan, Susunan Organisasi dan Tatakerja Sekretriat Majelis Rakyat Papua, Biro Organisasi Sekretariat Daerah Provinsi Papua, Jayapura. 
Poloma, Margaret M. 1992. Sosiologi Kontemporer, Terjemahan Yasogama, CV. Rajawali, Jakarta.

Ritzer, George.1985. Sosiologi Ilmu Berparadigma Ganda. terjemahan Alimandan. CV. Rajawali, Jakarta.

Ritzer, George - Douglas J. Goodman, 2004. Teori Sosiologi Modern, (Edisi-6), di Indonesikan Oleh Alimandan, Predana Media, Jakarta.

Sajogyo, Ny. Pudjiwati, 1985. Sosiologi Pembangunan, Fakultas Pasca Sarjana IKIP Jakarta bekerjasama dengan BKKBN, Jakarta.

Soemardjan, Selo dan Soeleman Soemardi. 1964. Setangkai Bunga Sosiologi. Lembaga Ekonomi UI, Jakarta.

Soekanto, Soerjono, 2007. Sosiologi Suatu Pengantar (Edisi Baru), PT Raja Grafindo Persada, Jakarta.

Suharto, Edi, 2005. Membangun Masyarakat, Memberdayakan Masyarakat, Refika Aditama, Bandung.

Wrihatnolo, Randy R. dan Riant Nugroho Dwidjojoto, 2007. Manajemen Pemberdayaan: Sebuah Pengantar Panduan untuk Pemberdayaan Masyarakat. PT. Elex Media Komputindo, Jakarta. 